ceive that the American statute purports to declare that the enforcement of a foreign limitation of liability would be offensive to our notions of justice, while at the same time enacting a limitation of liability substantially like those of foreign countries. If, on the other hand, the distinction is made between the substantive limit of liability and the steps whereby this limit may be obtained by a shipowner, the applicable policy arguments relevant to the conflict of laws all are in favor of the restricted scope of the statute. If these policy arguments and the correct conflict-of-laws theory were followed, the American courts would apply the monetary limit of the American statute only when referred to that statute by choice-of-law rules. But as matters now stand, insofar as The Titanic limits the applicability of foreign limitation of liability statutes, it operates as a last remnant of the idea that each nation should mete out the law of nations as it interprets that law. This notion has long been repudiated and has been superseded by the conflict of laws, a legal technique based upon a more realistic appraisal of world conditions. ${ }^{26}$

\title{
LEGAL STATUS OF INFANT EN VENTRE SA MÈRE
}

Traditionally the question of whether an infant can sue for injuries sustained while en ventre sa mère ${ }^{x}$ through the negligence of others has been answered in the negative. ${ }^{2}$ The principal reasons given for denying recovery have been: ${ }^{3}$

${ }^{6} \mathrm{~A}$ recent article in the Columbia Law Review agrees that The Titanic should be reexamined. Knauth, Renvoi and Other Conflicts Problems in Transportation Law, 49 Col. L. Rev. I (I949). Concerning the Black Diamond case, the author notes that three different suits are being brought against the owners. The British shipowners are suing in England, the cargo owners are suing in the United States, and a wreck removal suit will be brought in Belgium. He points out that if the United States and Great Britain both declare the limitation of liability to be a matter of procedure, "the parties plaintiff, by artfully dividing their lawsuits between these very three States (each of which has a statute limiting a shipowner's liability) will actually circumvent the common policy declared by all three States, and may succeed in recovering judgments aggregating over $\$ 2,000,000$ - or seven times the Belgian limitation statute figure -and will presumably collect on those judgments." In Mr. Knauth's opinion The Titanic will contribute to this result, although, "[t]he Court's ruling on the limitation point has always been a matter of some doubt, and it may now be re-examined in the Merganser-Norwalk Victory litigation [the Black Diamond case]."

$x$ The term "en ventre sa mère" refers to a child still within the mother's womb.

${ }^{2}$ Dietrich v. Inhabitants of Northhampton, I38 Mass. 44 (1884); Stemmer v. Kline, I28 N.J.I. 455, 26 A. $2 \mathrm{~d} 489$ (I942); Ryan v. Public Service Coordinated Transport, I8 N.J. Misc. 429, 14 A. 2d 52 (r940); Berlin v. J. C. Penney Co., 339 Pa. 547, I6 A. 2d 28 (1940); Smith v. Luckhardt, 299 Iil. App. 100, I9 N.E. 2d 446 (1939); Newman v. Detroit, 28I Mich. 60, 274 N.W. 7ro (I937); Magnolia Coca Cola Bottling Co. v. Jordan, x 24 Tex. 347, 78 S.W. 2d 944 (1935); Stanford v. St. Louis \& San Francisco Ry. Co., 214 Ala. 6r I, 108 So. 566 (1926); Drobner v. Peters, 232 N.Y. 220, 133 N.E. 567 (1921); Lipps v. Milwaukee Electric Ry. \& Light Co., 164 Wis. 272, I59 N.W. 916 (I916); Nugent v. Brooklyn Heights Ry. Co., I54 App. Div. 667,139 N.Y. Supp. 367 (19r3); Walker v. Great Northern Ry. Co. of Ireland, 28 I. R. Fr. 69 (I891). Contra: Bonbrest v. Kotz, 65 F. Supp. r38 (D.C. I946); Scott v. McPheeters, 33 Cal. App. $2 \mathrm{~d} 629,92$ P. $2 \mathrm{~d} 678$ (r939) (on the basis of a California statute); Montreal Tramways v. Leveille, [r933] 4 Dom. L.R. 337; Cooper v. Blanck, 39 So. $2 \mathrm{~d} 352$ (La. App., r923) (published in 1949). See also notes 12 and 13 , infra.

3 See Judge Pound's opinion in Drobner v. Peters, 232 N.Y. 220 . I33 N.E. 567 (r92I), in which he lists as reasons for denying recovery: I) lack of authority, 2) practical inconvenience 
(I) that the unborn child has no separate existence apart from its mother, and thus there is no individual to whom the tortfeasor owes a legal duty;4 (2) that there is a lack of precedent for permitting the infant to recover; 5 and that it is too difficult to prove that the injuries sustained by the unborn child were the result of the defendant's negligence. ${ }^{6}$ These reasons have been examined by textbook authors and other writers ${ }^{7}$ and rightly rejected by most of them. They have argued that since the interests of an infant en ventre sa mère have been protected in criminal and property law, ${ }^{8}$ there is no reason why these interests should not be protected under tort law. Lack of precedent and difficulties of proof of physical injury, particularly in view of the great advances medical science has made in recent years, ${ }^{9}$ should never be the grounds for denying relief.

Although the writers have been almost unanimous in rejecting the traditional rationale for denying the unborn child's claim, they have, nevertheless, accepted the distinction made in some of the cases ${ }^{\mathrm{IO}}$ between injury to a viable child and injury to a nonviable child. ${ }^{\mathrm{II}} \mathrm{It}$ is said that recovery would be per-

and possible injustice, 3) no separate entity apart from the mother and, therefore, no duty of care, and 4) no person or human being in esse at the time of the accident.

4 This was Judge Holmes's rationale in the leading case of Dietrich v. Inhabitants of Northhampton, I38 Mass. I4 (I884) and this reasoning was followed in most of the succeeding cases denying recovery. See also Prosser on Torts I88 (I94I); 52 Am. Jur. 440 (I944).

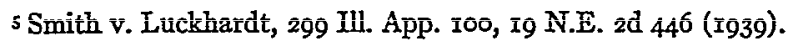

${ }^{6}$ Magnolia Coca Cola Bottling Co. v. Jordan, x24 Tex. 347, 78 S.W. $2 d 944$ (1935).

7 Prosser on Torts I88 (I94I); Albertsworth, Recognition of New Interests in the Law of Torts, Io Calif. L. Rev. 46I, 463 (x922); Frey, Injuries to Infants en Ventre sa Mère, I2 St. Louis I. Rev. 85 (I927); Straub, Right of Action for Pre-natal Injuries, 33 Law Notes 205 (r930); 35 Ill. Bar J. 266 (I947); 20 So. Calif. L. Rev. 23I (1947); 26 Neb. L. Rev. 43 I (I947); ${ }_{15}$ U. of Kan. City L. Rev. 66 (I947); 32 Corn. L. Q. 609 (I947).

8 The authorities on this point are voluminous. The following from a note in 44 Yale I. J. $I_{4} 68, I_{469}$ (I935) summarizes the state of the law quite well: "It is not true, however, that for all purposes a child en ventre sa merre is non-existent, either physically or legally. Thus in the law of property he is in esse for all purposes which are to his benefit. He may take by descent or under a will or marriage settlement, have a guardian appointed, be made an executor, and, through his guardian, may secure an injunction to stay waste. The criminal law also regards him as a separate entity. Thus it has been held that when a child born alive dies as a result of prenatal injuries inflicted by an unlawful beating of the mother, the wrongdoer is guilty of murder."

9 See Maloy, Legal Anatomy and Surgery 669-87 (I930); Herzog, Medical Jurisprudence $\$ \$ 860-975$ ( $\mathrm{x} 93 \mathrm{r})$.

to This distinction, which is also of significance in the abortion cases in criminal law, was suggested by Holmes in the Dietrich case and followed in almost all of the subsequent cases dealing with prenatal injuries. In Lipps v. Milwaukee Electric Ry. \& Light Co., r64 Wis. 272, I59 N.W. 9 r6 (I9I6), the court denied recovery only because the rights of a nonviable child were involved. Both Bonbrest v. Kotz, 65 F. Supp. I38 (I946) and Cooper v. Blanck, 39 So. 2d 352 (1923) which permitted recovery explicitly limited the holding to recovery for injury to a viable child.

II A viable child is one that is capable of living outside its mother's womb and depends on its mother for sustenance only. The term is used here as describing a stage of foetal develop- 
mitted only in the former situation, because the nonviable child is not an entity capable of suffering injury. Two recent cases, one in Minnesota ${ }^{\mathrm{x} 2}$ and the other in Ohio, ${ }^{{ }^{3}}$ permitted recovery on the basis of this distinction. In the former case, a viable child died prior to birth as result of the doctor's negligence in treating its mother, while in the latter the infant plaintiff was injured when its mother fell from the steps of a bus operated by the defendant's servants in a negligent manner.

This "viable and nonviable" distinction has been defended on the ground that it reduces speculation as to whether the defendant's negligence was the cause of the injury, and thus helps to surmount the difficult problem of proof. ${ }^{{ }^{14}}$ But if the reasons given above for investing the unborn child with a legal personality are valid, this distinction is unsound, for it should make no difference at what stage of embryonic development the foetus is when injured.

There is an interesting aspect of these "en ventre sa mère" cases which neither the writers nor the cases have considered. Assuming that the personality and proof difficulties barring the unborn child's recovery are discounted as unsound, can the infant, consistent with modern theories of tort liability for negligence, recover? Although it is obvious why the courts which did not recognize the infant as a legal entity did not address themselves to this problem, it is not so obvious why the few courts which did permit the infant to recover ignored this question. Perhaps these courts felt that the result of such an inquiry would be self-evident, for, as the infant en ventre sa mère is in a sense part of the mother, proof of negligence toward the latter would be proof that there was negligence toward the former. But if the infant is to be recognized as a separate legal entity, its cause of action should be determined solely on its own merits. Present tort law in the United States has, to a great extent, rejected the policy of imposing unlimited liability. ${ }^{15}$ Liability for negligence is discussed in such limiting terms as duty, foreseeability, or proximate cause, which cut down the responsibility of a negligent defendant to the point where his legal liability is commensurate with his wrong. Judge Cardozo, in Palsgraf v. The Long Island $R$. Co ${ }^{16}$ discussed some of the principles limiting liability in negligence cases. ${ }^{17}$

ment. It should be noted, however, that medical science regards the child as in being from the moment of its conception. See note 9 supra.

12 Verkennes v. Corniea, 38 N.W. 2 d 838 (Minn., 1949) (personal representative of infant permitted to maintain action under a wrongful death statute).

${ }^{23}$ Williams v. Marion Rapid Transit, Inc., 87 N.E. 2d 334 (Ohio, I949).

${ }^{4}$ See $x_{5}$ U. of Kan. City L. Rev. 66 (x947).

15 See Holmes, The Common Law ro5 (I88I).

${ }^{26} 248$ N.Y. 339 , 162 N.E. 99 (I928).

27 This opinion has been the object of much discussion, and various interpretations of Cardozo's opinion have been offered. See Gregory, Proximate Cause in Negligence, A Retreat from Rationalization, 6 Univ. Chi. L. Rev. 36 (I938); Prosser on Torts, I84 (I94I); Seavey, Mr. Justice Cardozo and the Law of Torts, 52 Harv. L. Rev. 372, 38 I (I939); Green, Judge and Jury 244 (r930). 
Negligence, he said, is a term of relationship. The defendant, to be negligent, must be negligent with respect to a particular person, and the hazard which his negligence has set up must foreseeably be capable of causing an injury to that individual. ${ }^{.8}$ "The risk reasonably to be perceived defines the duty to be obeyed, and risk imports relation; it is risk to another or to others within the range of apprehension." "'s9

If, then, negligence is a matter of relation which must be founded upon the foreseeability of the hazard causing harm to the person injured, can the infant plaintiff in the prenatal injury cases recover? The result may depend on whether the tortfeasor is, or should be, aware of the existence of the unborn child. ${ }^{20}$ Where, as in the medical malpractice cases, the infant's presence is or should be known, it is foreseeable that the negligence of the tortfeasor may cause injury, and the infant should certainly be permitted to recover..$^{2 x}$

A more difficult problem arises in the automobile or train accident situation where the defendant is unaware of the existence of the infant en ventre sa mère, and where to hold him liable for the injuries suffered by the unborn child may be imposing upon him too great a financial responsibility. In a much discussed Wisconsin case, ${ }^{22}$ the court refused to hold the defendant liable for the death of a mother who suffered a miscarriage on seeing her son run down by the defendant. The imposition of such a duty on the tortfeasor, the court believed, would be imposing liability wholly out of proportion to the culpability of the negligent party. This reasoning is applicable here. If it is assumed that there will always be a certain proportion of women pregnant then the defendant can reasonably be expected to contemplate the possibility that his negligence may result in injury to an infant en ventre sa mère, and he should be held liable. But if such an assumption is not made, then, by holding the defendant liable, an unreasonable burden would be placed upon a negligent tortfeasor, for the risk here is one that is not reasonably to be perceived.

The same difference in result might ensue if these cases are determined on the basis of a "proximate cause" rationale. The particular result will depend on what theory of liability the term "proximate cause" represents. If, in accord with what is widely held to be the English view, ${ }^{23}$ a defendant is held liable for

${ }^{18}$ The cases dealing with liability for negligent use of words seem to lend support to this theory. See Ultramares Corp. v. Touche, 255 N.Y. I 70, I74 N.E. 44I (x93I); Courteen Seed Co. v. Hong Kong \& Shanghai Banking Corp.; 245 N.Y. 337, I57 N.E. 272 (I927); Jaillet v. Cashman, 235 N.Y. 5 II, I39 N.E. 714 (1923); Glanzer v. Shepard, 233 N.Y. 236, I35 N.E. 275 (I922).

19 Palsgraf v. The Long Island Ry. Co., 248 N.Y. 339, 344, x62 N.E. 99, roo (x928).

${ }^{20}$ See Boggs's dissent in Allaire v. St. Luke's Hospital, 184 Ill. 359, 56 N.E. 638 (Igoo).

${ }^{2 x}$ In Bonbrest v. Kotz, 65 F. Supp. ${ }_{3} 8$ (D.C. I946), the infant plaintiff was injured through the malpractice of the surgeon in removing it from its mother's womb. The court held that the plaintiff's complaint stated a good cause of action.

22 Waube v. Warrington, 216 Wis. 603, 258 N.W. 497 (1935).

${ }^{23}$ Smith v. London \& South Western Ry. Co., L.R. 6 C.P. $x_{4}$ ( 1870 ); In re Polemis, [rg2x] 3 K.B. 560 ; Hambrook v. Stokes, [1925] I K.B. I4I. Here the court permitted the plaintiff to 
all the consequences that can be traced to his negligence whether the hazard thereby set up is foreseeable or not, the defendant, in these prenatal injury cases, should be held responsible. If, however, a court feels that a defendant's negligence is the proximate cause of a plaintiff's injury only if the hazard to the plaintiff can be foreseen, ${ }^{24}$ then the tortfeasor may or may not be held liable depending on whether the hazard set up was foreseeable.

The treatment of the responsibility of the defendant to the infant as an ordinary question of liability for negligence gives rise to another problem: The infant plaintiff may be met with the defense that the contributory negligence of the mother should be imputed to it and thus bar its recovery. Some of the older cases did recognize the defense of imputed contributory negligence where an extremely young child, negligently allowed by its parents or guardians to become exposed to danger, was injured by a negligent defendant. ${ }^{25}$ These decisions were based on the argument that the custodian was the infant's agent for its care and thus, with respect to third persons, the neglect of the agent was the neglect of the infant. The later cases repudiated this reasoning ${ }^{26}$ and permitted the child to recover on the ground that the guardian or parent was not the agent of the infant, but of the law. There was, therefore, no relationship on which to base the imputation of negligence. ${ }^{27}$ The result in these latter cases seems to be the preferable one. Ordinarily, the plaintiff who has been contributorily negligent is prevented from recovering not because of any solicitude for the tortfeasor, but rather because of a policy of the law against permitting a party to profit by his own lack of prudence and care. ${ }^{28}$ However, this reason does not

recover on facts almost identical with those in Waube v. Warrington, 216 Wis. 603,258 N.W. 497 (1935).

${ }^{24}$ Proximate cause can also be used to describe the proposition that even if the defendant was negligent in some respects and even if the negligence was in fact causally contributive to the harm complained of, the court will nevertheless direct a verdict for the defendant if, in its opinion, the eventuality complained of was not a foreseeable incident of the defendant's negligence: Wood v. Pa. Ry. Co., I77 Pa. 306, 35 Atl. 699 (1896); Hoag v. Lake Shore \& Michigan Southern Ry. Co., 85 Pa. 293 (1877); Ryan v. N.Y. Central Ry. Co., 35 N.Y. 210 (I866).

${ }_{25}$ The leading case for this view is Hartfield v. Roper, 2I Wend. (N.Y.) 6I5 (I839).

${ }^{26}$ Warren v. Manchester St. Ry., 70 N.H. 352, 47 Atl. 735 (1900); Newman v. Phillipsburg Horse Car Ry. Co., 52 N.J.L. 446 (I89o); Bellefontaine \& Indiana Ry. Co. v. Snyder, I 8 Ohio St. 399 (1868). These cases set the pattern for all the modern cases on this point.

27 Underlying the cases permitting the child to recover in spite of the negligence of its parent or guardian is the view that the relationship required for the imputation of negligence is such that the child plaintiff, if he were being sued as a defendant for the negligence of the parent, would be held vicariously liable. Since it is manifest that the child cannot be so held, these cases have said that it would not be logical to impute the guardian's negligence. But, it has been maintained by Gregory in his articles on Imputed Contributory Negligence in 2 Univ. Chi. L. Rev. I73 (r935) and 4I Yale L.J. 83 I (I932), that this requirement is unsound because the reason behind the imposition of vicarious liability - that of providing a financially responsible defendant for an injured party to sue-is not the reason for the imputation of negligence.

${ }^{28}$ In Bellefontaine \& Indiana Ry. Co. v. Snyder, 18 Ohio St. 399, 409 (I868) the court listed as the reasons for barring a contributorily negligent plaintiff's claim: $(x)$ the mutuality of wrong involved would entitle each party alike, where both are injured, to an action against the 
apply when the rights of an infant injured while en ventre sa mère are under consideration, for the child has been guilty of no wrong or omission. Otherwise a great injustice might be done if financial protection were to be denied to a youngster who may have suffered a permanent injury.

\section{CONSIDERATION OF PUNISHMENT BY JURIES}

It is frequently stated that juries in criminal cases are to determine the question of guilt or innocence from the evidence alone and that a consideration of the severity of the penalty to be imposed should not influence their verdict. ${ }^{\mathrm{I}}$ Observance of this rule is essential to the preservation of the doctrine of "reasonable doubt, ${ }^{\prime \prime 2}$ since the slightest consideration of a light sentence or of a quick parole may exert just the degree of influence necessary to persuade the doubtful juror to agree to a verdict of guilty. ${ }^{3}$ Moreover, since juries are not to be judges of the law, 4 they should not be given the opportunity to decide that

other, (2) it is unfair to allow a party to recover for his own wrong, and (3) it is a policy of the law to make the personal interests of the parties dependent upon their own prudence and care.

I People v. Sherman, 264 App. Div. 274, 35 N.Y.S. 2d I7I (I942); People v. Warner, 289 Mich. 516, 286 N.W. 8 II (1939); State v. Doucet, 177 La. 63, I47 So. 500 (1933); State v. Lunsford, I63 Wash. I99, 300 Pac. 529 (I93I); State v. Bell, 206 Iowa 8I6, 22 I N.W. 52I (I928); People v. Santini, 22I App. Div. 139, 222 N.Y. Supp. 683 (1927); Liska v. State, Ir 5 Ohio St. 283, I52 N.E. 667 (I926); State v. Kernan, I54 Iowa 672, I35 N.W. 362 (r9I2); State v. Satcher, I24 La. xoI5, 50 So. 835 (rgog); State v. Gill, I4 S.C. 4 Io (1880).

2 A well known definition of the term "reasonable doubt" is that expressed by Chief Justice Shaw in Commonwealth v. Webster, 5 Cush. (Mass.) 295, 320 (1850). It is "that state of the case, which, after the entire comparison and consideration of all the evidence, leaves the minds of jurors in that condition that they cannot say they feel an abiding conviction, to a moral certainty, of the truth of the charge.... The evidence must establish the truth of the fact to a reasonable and moral certainty - a certainty that convinces and directs the understanding and satisfies the reason and judgment. ..."

It is stated in Wigmore, however, that this degree of certainty is an "elusive and undefinable state of mind." He suggested that all efforts toward definition be abandoned and that juries be left to apply "reasonable doubt" as words of common usage. 9 Wigmore, Evidence $\$ 2497$ (3d ed. I940).

3 "[Considering] that a very slight circumstance may affect the verdict, the danger from putting before the jury anything that may improperly influence their deliberations becomes more apparent." Miller v. United States, 37 App. D.C. r38, r44 (rgrI). If the jury receives the impression that the penalty may not be serious, such impression will be almost certain to affect the verdict in doubtful cases.

4 A. L. I. Code of Crim. Proc. $\$ 323$ (I93I); 23 C.J.S. Criminal Law $\S$ III8, at 6 I6 n. 57 , 58 (I940). To an extent the right to bring in a general verdict gives to a jury the power to determine the law as well as the facts by acquitting a defendant in opposition to the court's instructions on the law. If this power is improperly exercised, the error is not remediable, since a defendant may not be tried twice for the same crime. It is usually stated that a jury has the power to disregard the law as explained by the court, but not the moral right to do so. Commonwealth v. Castellana, $277 \mathrm{~Pa}$. II7, I2I Atl. 50 (I923); Brown v. Commonwealth, 86 Va. 466 , xo S.E. 745 (I89o); I6 C.J. Criminal Law $\$ 2273$, at $922 \mathrm{n} .2$ (r9I8). In some jurisdictions, however, it has been held that it is legally permissible for a jury to disregard a court's instructions on the law, and that the judge may give an instruction to this effect. Hengstler v. State, 